Article

\title{
Exploitation Contradictions Concerning Multi-Energy Resources among Coal, Gas, Oil, and Uranium: A Case Study in the Ordos Basin (Western North China Craton and Southern Side of Yinshan Mountains)
}

\author{
Xiaowei Feng ${ }^{1}$, Nong Zhang ${ }^{1, *}$, Xiaoting Chen ${ }^{2}$, Lianyuan Gong ${ }^{3}$, Chuangxin Lv ${ }^{4}$ and Yu Guo ${ }^{1}$ \\ 1 Key Laboratory of Deep Coal Resource Mining, Ministry of Education of China, \\ China University of Mining and Technology, Xuzhou 221116, China; \\ fxw_mining@foxmail.com (X.F.); hnnygy@126.com (Y.G.) \\ 2 Faculty of economics and business, University Malaysia Sarawak, Kota Samarahan 94300, Malaysia; \\ 15020175@siswa.unimas.my \\ 3 Key Laboratory of Coal Processing and Efficient Utilization, Ministry of Education of China, \\ School of Chemical Engineering and Technology, China University of Mining and Technology, \\ Xuzhou 221116, China; gly_huagong@foxmail.com \\ 4 Department of Civil and Environmental Engineering, Hong Kong University of Science and Technology, \\ Kowloon 999077, Hong Kong, China; lcxcumt@163.com \\ * Correspondence: zhangnong@126.com; Tel.: +86-516-8359-0502
}

Academic Editor: Peter V. Schaeffer

Received: 24 November 2015; Accepted: 15 February 2016; Published: 19 February 2016

\begin{abstract}
The particular "rich coal, meager oil, and deficient gas" energy structure of China determines its high degree of dependence on coal resources. After over 100 years of high-intensity mining activities in Northeast China, East Region, and the Southern Region, coal mining in these areas is facing a series of serious problems, which force China's energy exploitation map to be rewritten. New energy bases will move to the western and northern regions in the next few years. However, overlapping phenomena of multiple resources are frequently encountered. Previous exploitation mainly focused on coal mining, which destroys many mutualistic and accompanying resources, such as uranium, gas, and oil. Aiming at solving this unscientific development mode, this research presents a case study in the Ordos Basin, where uranium, coal, and gas/oil show a three-dimensional overlapping phenomenon along the vertical downward direction. The upper uranium and lower coal situation in this basin is remarkable; specifically, coal mining disturbs the overlaying aquifer, thus requiring the uranium to be leached first. The technical approach must be sufficiently reliable to avoid the leakage of radioactive elements in subsequent coal mining procedures. Hence, the unbalanced injection and extraction of uranium mining is used to completely eradicate the discharged emissions to the environment. The gas and oil are typically not extracted because of their deep occurrence strata and their overlapping phenomenon with coal seams. Use of the integrated coal and gas production method is recommended, and relevant fracturing methods to increase the gas migrating degree in the strata are also introduced. The results and recommendations in this study are applicable in some other areas with similarities.
\end{abstract}

Keywords: coal; uranium; oil; gas; mining; exploitation contradictions; Ordos Basin

\section{Introduction}

Energy is an indispensable resource for mankind, and this dependency is becoming increasingly obvious in the 21st century. This increasing dependency is accompanied by a series of new emerging 
energy sources, such as wind energy, hydropower, and nuclear power. China has the third largest national territory area in the world, and there are abundant amounts of energy of various types. Nonetheless, the energy structure of China has long been dominated by its "rich coal, meager oil, and deficient gas" and coal consumption accounts for more than $70 \%$ of the country's total energy consumption. Based on the China Mineral Resources 2014 released by the Ministry of Land and Resources of the People's Republic of China [1], there are 1484.29 billion tons, 3.37 billion tons, and 4642.88 billion cubic meters of coal, oil, and gas reserves, respectively. Figure 1 shows the top-ranked energy production countries in recent years [2], and it also illustrates the special energy structure mode of China.

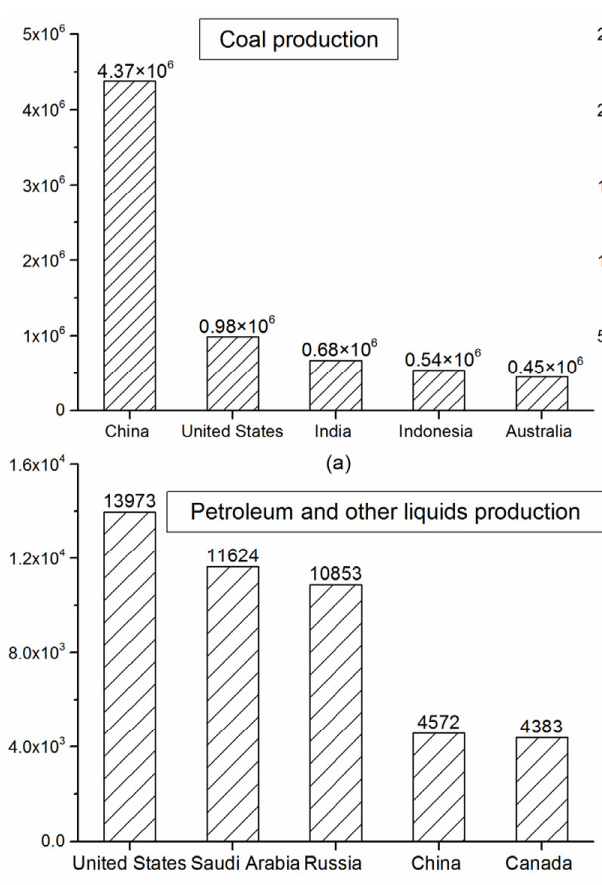

(c)

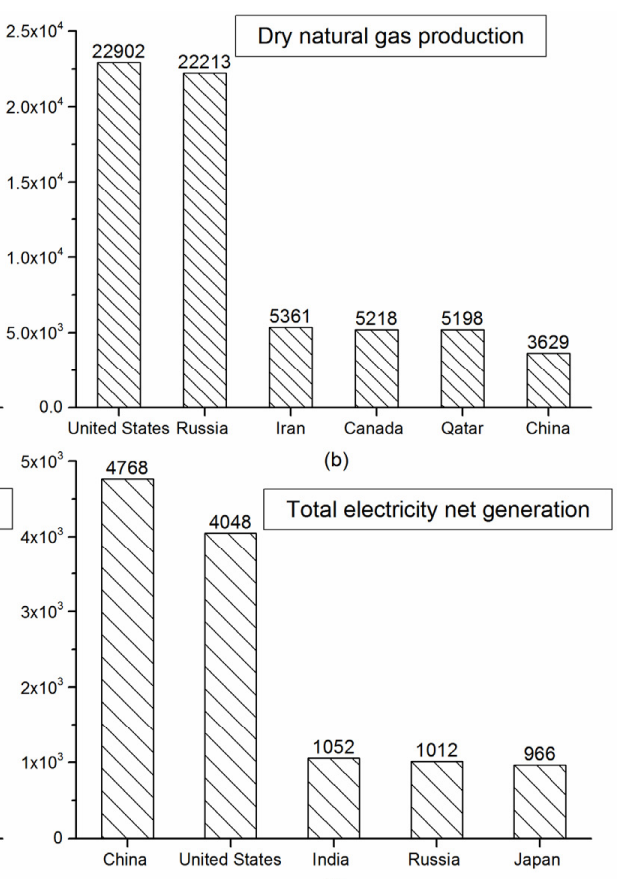

(d)

Figure 1. Top-ranked energy production countries in recent years. (a) Top five coal production countries in 2013 (thousand short tons); (b) Top five dry natural gas production countries and their comparison with China in 2011 (billion cubic feet); (c) Top five petroleum and other liquids production countries in 2014 (thousand barrels per day); (d) Top five total electricity net generation countries in 2012 (billion kilowatt-hours) * * To guarantee accuracy, only the most recent years with sufficient data were analyzed.

Figure 2 displays all large coal-bearing basins in China and their dominating mountains. After nearly 100 years of modern coal mining activities in mainland China, a large number of coal basins are facing a series of problems from multiple aspects. In the past thirty years, coal resources in the northeast China region have been on the verge of depletion, and many cities such as those in the Songliao Basin, Mohe Basin, and Hailaer Basin, are currently being forced to transform themselves from a traditional single coal-oriented economy structure [3]. Compared to these basins, basins located in the eastern region or southern region are also facing serious problems, with the most urgent one being the large annual increase in the mining depth (6-12 $\mathrm{m}$ /year) because of resource exhaustion near the ground surface. To seek as much income as possible, some coal mines try to explore resources buried deep, even more than $1500 \mathrm{~m}$ below the surface, where coal mining faces increased technological difficulties, mining costs, and safety concerns. Since 2012, coal production in China has been undergoing an abnormal period, and the coal economy has suffered greatly because of downward macro-economic pressure and environment protection pressure. Hence, it is unwise to explore coal resources at a higher cost. Furthermore, coal production in the eastern or southern regions of China is known for its high cost, serious environment pollution, and unresolved technological problems [4]. 


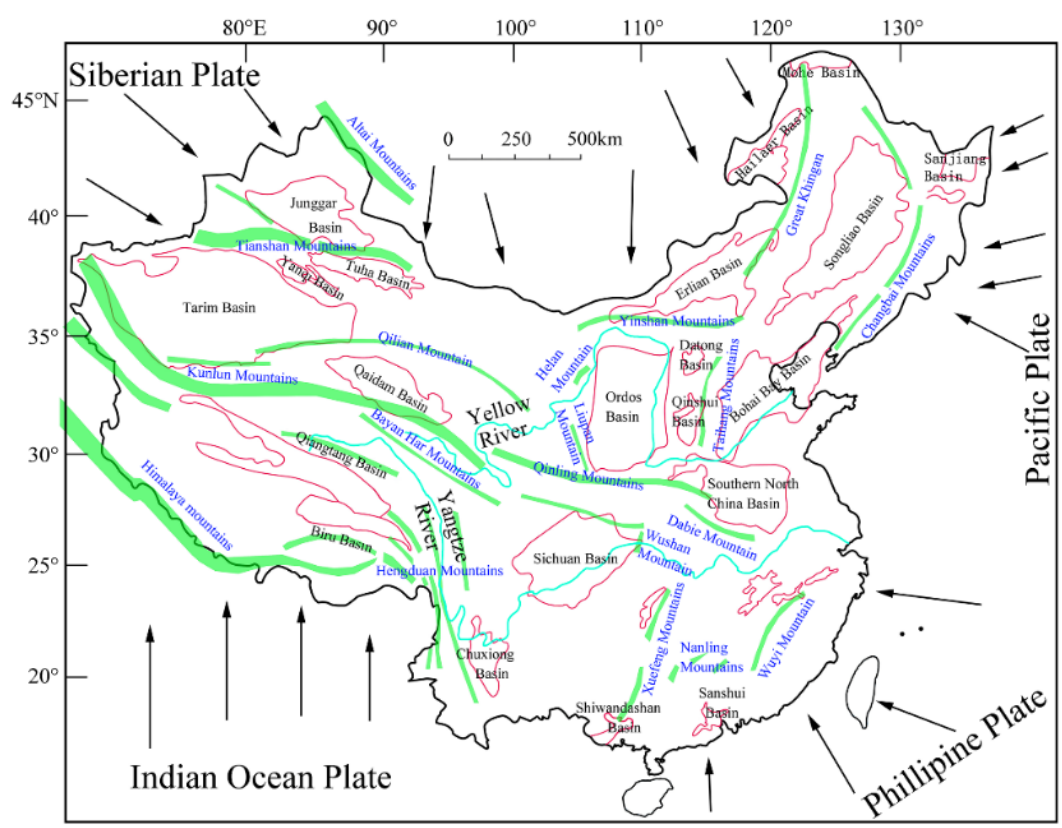

Figure 2. Large coal-bearing basins in China and their dominating mountains.

Based on the aforementioned analysis, new energy resource bases should move to the western and northern regions of China, and the latest "Energy Development Strategic Action Plan from 2014 to 2020" released by the General Office of the State Council of the People's Republic of China confirms this notion [5]. Coal-bearing basins in these regions are more feasible for exploration because of their ideal geological conditions and because the depth of the coal is considerably shallower than in the eastern regions. Furthermore, there are no intricate faults that cut the original intact coal field into scattered coal fragments, thus avoiding mining difficulties and safety concerns. There is also no unpredictable karst water or symbiotic gas in the coal seam. The former may induce a sudden water inrush, and the latter may induce a momentary coal mine explosion. Moreover, ground stress in these basins is quite low because of the shallow buried depth and the relatively simply geological movements. Hence, there will not be a high supporting cost to stabilize the normal working space underground. Therefore, in the foreseeable future, energy production bases will inevitably transfer to western basins, such as the Tarim Basin and Qaidam Basin, and northern basins, such as the Ordos Basin and Erlian Basin.

Coal is a resource that initially evolves from plants over hundreds of millions of years. During this process, some other energy sources may come into being simultaneously, including natural gas. In most old engineering practices, natural gas is perplexing to many engineers because of its unstable properties, and it can easily result in large mine disasters and numerous fatalities. According to the Analysis Report of National Coal Mine Accidents in 2013 released by the State Administration of Coal Mine Safety, the proportional distribution for deaths under different inducements is shown in Figure 3. Gas explosions are the leading cause of deaths in coal mining activities. In recent years, practitioners have explored numerous methods to solve this problem and to take advantage of this mutualistic resource of coal; fortunately, there is a new measure called Integrated Coal Production and Gas Extraction, which will be discussed in the following sections [6-8].

Furthermore, kaolinite, oil shale, and oil can also exist in coal-bearing strata, and these resources undoubtedly play an important role in the national economy. However, coal exploitation has long been destructive to other accompanying/mutualistic resources. This paper focuses on the resources' mutualistic and accompanying occurrence in the Ordos Basin, which provides certain reference significance to the regions sharing the same resources. 


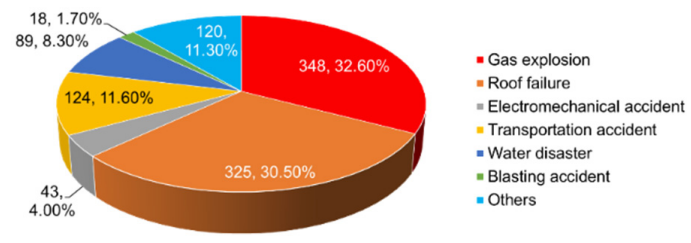

Figure 3. Proportional distribution of deaths induced by coal disasters in 2013.

\section{Resources in the Study Area}

\subsection{Brief Introduction to the Ordos Basin}

Ordos (phonetically means numerous palaces), surrounded by the Yinshan Mountains to the north, the Qinling Mountains to the south, the Helan Mountain and Liupan Mountain to the west, and the Taihang Mountain to the east, is called the "sea of resources". It is also half embraced by the Yellow River from its eastern, northern, and western sides (Figures 2 and 4), thus making it the second largest inland sedimentary basin in China. Over billions of years of geological evolution, the tectonic movement in the Ordos Basin shows a general mitigating trend [9]. Nonetheless, the peripheral regions are historically dominated by drastic tectonic movements, and a general distribution of seismic activities can be outlined along the peripheral faults $[10,11]$, as shown in Figure 4 . This type of natural geological condition with active surroundings and a central plateau provides an excellent environment for the appropriate sedimentation of more than 50 types of resources [12]. Among them, the reserves for coal, gas, and sandstone-hosted uranium are particularly important for national strategic development. The proved coal and gas reserves (as of December 2014) are 213.3 billion tons and 1789.3 billion cubic meters, respectively, which account for $13.7 \%$ and $17.3 \%$ of the national reserve, respectively. Uranium exploration is under investigation, and a large uranium metallogenic belt has already been found in the Dongsheng area in the northern part of the Ordos Basin $[13,14]$.

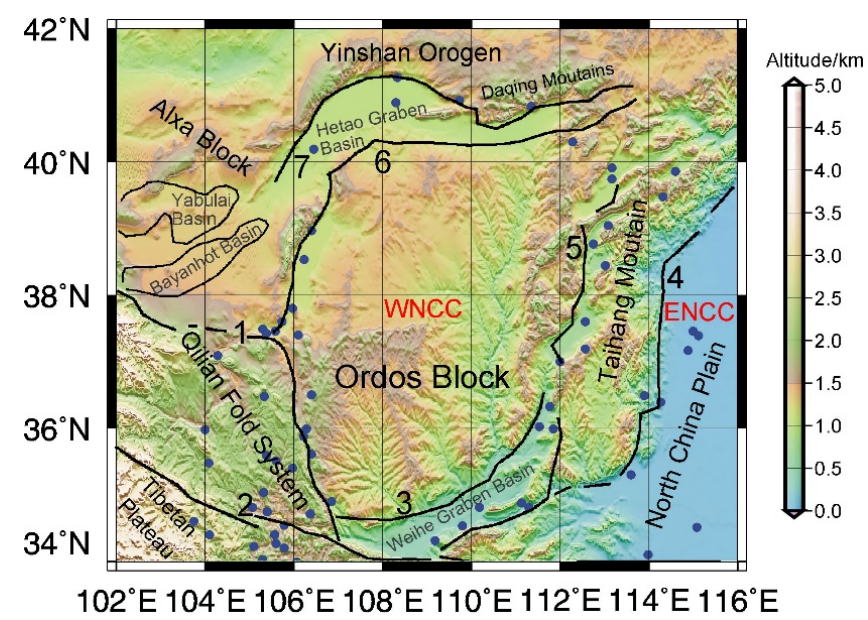

Figure 4. Topography, tectonics, and seismicity of the Ordos region. Blue dots indicate epicenters of earthquakes with magnitudes larger than 6.0 since 1000 A.D [15]. Numbers indicate some dominating faults, where 1: Qingtongxia Fault, 2: Gansu Fault, 3: Weihe Fault, 4: Tanlu Fault, 5: East Margin of the Luliang Fault, 6: Huanghe Fault, and 7: South Margin of the Yinshan Fault. The abbreviations indicate dominating basins and blocks; WNCC and ENCC represent the eastern block of the North China Craton and the western block of the North China Craton, respectively.

\subsection{Resources in the Ordos Basin}

Following a bottom-up sedimentary direction, the strata in the Ordos Basin can be divided as Palaeozoic Ordovician, Carboniferous, Permian, Mesozoic Triassic, Jurassic, Cretaceous, Cenozoic 
Palaeogene, and Quaternary. Strata deposits in this area have sequentially undergone an evolution of the marine sediment, interactive marine and terrestrial sediment, and terrestrial sediment since the Ordovician. Hence, certain thick strata could be forged, and many types of minerals could be reserved in different evolution periods. Different minerals have different occurrence strata. Thus, a general unique mutualistic and accompanying occurrence pattern becomes visible from both the horizontal and vertical prospectives. Table 1 presents detailed stratigraphic horizons of different minerals. The superimposed resources create considerable potential for local economy development, but it can also induce great difficulties in appropriate exploitation without additional adverse environmental effects and resource breakage/waste incidences.

Table 1. Stratigraphic horizons for some of the main minerals in the Ordos Basin.

\begin{tabular}{|c|c|c|c|c|c|c|}
\hline Stratigraphic Horizon & Coal & Natural Gas & Coalbed Methane & Uranium & Kaolinite & Oil Shale \\
\hline \multicolumn{7}{|l|}{ Quaternary } \\
\hline \multicolumn{7}{|l|}{ Palaeogene } \\
\hline \multicolumn{7}{|l|}{ Cretaceous } \\
\hline Jurassic & $\bullet$ & - & $\bullet$ & $\bullet$ & • & $\bullet$ \\
\hline Triassic & & 0 & & & & \\
\hline Permian & $\bullet$ & - & $\bullet$ & & $\bullet$ & \\
\hline Carboniferous & - & $\bullet$ & $\bullet$ & & $\bullet$ & \\
\hline Ordovician & & $\bullet$ & & & & \\
\hline
\end{tabular}

Coal-bearing strata include the Carboniferous Taiyuan Formation, Permian Shanxi Formation, and Jurassic Yanan Formation, and the coal resources are fairly well distributed over the basin. The three largest coal fields are the Jungar Qi field, Dongsheng field, and Table Mountain field from east to west. The general properties of the coal seam in this basin are considered stable, with a full range of coal types, shallow burial depth, and low mining cost. The largest coal mine, the Bulianta coal mine of the Shendong Group, can obtain an approved annual coal production of 28 million tons, which is unparalleled even from a global prospective.

The main horizon for oil and gas is Permian, and the relative distribution areas are the Uxin Banner, Etuoke Banner, Haggin Banner, and Etuokeqian Banner. The general burial depth for oil and gas surpasses $1500 \mathrm{~m}$, and this depth exceeds that of coal resources, with a depth of no more than $1000 \mathrm{~m}$. Hence, the exploration of oil and gas may cause certain difficulties for the exploration of coal. In 2014, 1.93 million tons and 28.1 billion cubic meters of crude oil and gas were produced in the Ordos Basin, respectively. Additionally, based on the continuous investigation on shale gas resources, it is predicted that reserves for shale gas can reach 1.5 billion cubic meters or more.

Uranium was deposited in the Zhiluo Formation of the Middle Jurassic and Lower Cretaceous with a general burial depth ranging from 550 to $750 \mathrm{~m}$. The primary distribution areas are the Haggin Banner, Ejin Horo Banner, Dongsheng area, and Etuokeqian Banner. Uranium, which serves as a vital strategic and new resource, has the capability of counteracting the total energy released by 2.70 million tons of standard coal with only 1 ton of $U^{235}$. The strength of this type of energy is unmeasurable. Comparing the thermal power based on coal and nuclear power based on uranium by the measure of generating 10 billion $\mathrm{kWh}$ gives the following fact: the same $\mathrm{kWh}$ will cost 3.39 million tons of standard coal and simultaneously produce 2.03 million tons of carbon dioxide, 77.80 thousand tons of sulfur dioxide, 700 thousand railway carriages for transportation, and a large amount of coal ash/cinder; the same kWh costs only 52 tons of nuclear fuel and one railway carriage with zero emissions. Furthermore, the demands for energy and environmental protection are increasing worldwide, and nuclear power has numerous advantages, such as being clean, safe, and efficient. An increasing number of countries have been developing nuclear power in recent years. The uranium resource in Ordos Basin has been an unexplored and unknown situation for many years; only in recent years has it begun to draw public attention, which has considerable potential for China's energy development. 


\section{Mutualism and Accompanying Situation among the Multiple Resources in the Ordos Basin}

As the largest energy-based resources aggregation area in China, one prominent problem is properly exploiting each type of resource and simultaneously avoiding disturbing the exploration of other resources. The mutualism and accompanying situation of uranium, coal, gas, and oil causes many technical difficulties. Their plane projections can overlap with each other, and their vertical horizons also vary with each other. Following a downward direction, the generally dimensional sequence for all resources is uranium, coal, oil, and gas. The vertical distance between uranium and coal is quite small, whereas the oil and gas are located at the bottom horizon.

\subsection{General Development Induction of Coal Resources}

Under current coal mining technology in China, coal mining methods can be divided into underground mining and surface mining. The former can be subdivided into the long-wall mining method, top coal caving method, and the room and pillar mining method. Chinese coal production largely uses the underground mining method.

The long-wall mining method is widely used throughout the world because of its safety, considerable efficiency, and low cost. It is worth noting that top coal caving method also has many technical and economic superiorities such as high production and efficiency, low cost on roadway constructions, and strong adaptability to geological conditions, etc. However, this method is not applicable to the exploitation on mutualism and accompanying resources presented in this study because it causes complicated movement of overlying strata, unpredictable cracks development above the coal seam, and unstable abutment pressure of strata. For a long-wall mining method, the mining face is generally equipped with a coal cutter, self-advancing supports, and a scraper conveyer. The first step is to cut integral coal into blocks from the coal wall by coal cutter, and then these blocks are transferred by scraper conveyer. The self-advancing supports hold up the roof to guarantee a normal working space. The coal mining face is not a settled working place but a moving place. To compensate for the space in which the coal is found, the overburden roof strata are disturbed in the order of severity from the immediate roof toward the surface $[16,17]$. In general, if the ratio between the coal occurrence depth and mining height is larger than 40 [18], then four zones of different fracture degrees can be formed along the vertical direction, namely, the caved zone, fractured zone, continuous bending and deformation zone, and soil zone [19-21], as illustrated in Figure 5.

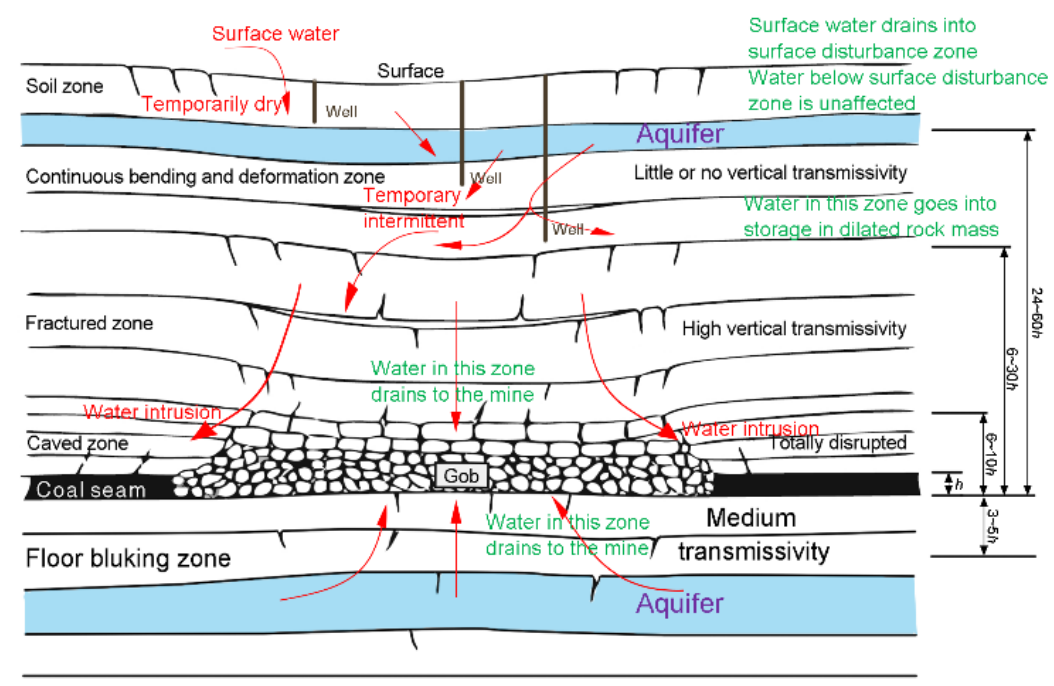

Figure 5. Overburden movement resulting from long-wall mining (modified from Kendorski's work [20]).

The caved zone is mainly comprised of irregular yet generally platy rock blocks of various sizes, and the height of this zone is determined by the broken rock volume, which is considerably 
larger than its original intact strata. The bending effects above the caved zone will cause numerous non-penetrating or penetrating cracks in the strata, and the stratum will break into large hinged or half-hinged blocks, which is the fractured zone. Nonetheless, the neighboring blocks can still come into contact with each other either fully or partially. Above the fractured zone is the continuous bending and deformation zone, and major cracks penetrating the entire layer of the strata, as in the fractured zone, are rarely observed in this zone. The strata deform gently and induce only some minor cracks in its rock mass. At a certain depth under the surface is the soil zone, and the newly formed cracks due to bottom mining can open and close automatically as the mining face comes and goes. Additionally, the stress in the floor (strata closing to the bottom side of the coal seam) will be redistributed because of mining activities, peripheral stress will force the floor to heave upward to adapt the stress distribution as much as possible. This will initiate cracks in the floor, but the extension and evolution of these cracks are relatively minor compared to those in the caved zone or fractured zone. Anyway, the volume of certain region of rock mass in the floor will increase to create a "bulking" effect, which is the floor bulking zone under the coal seam.

These zones have a large influence on the water migration among them $[22,23]$. The caved zone is completely disrupted, and the water can intrude easily. The floor bulking zone has a medium transmissivity for water penetration. The fractured zone has a high vertical transmissivity. The continuous bending and deformation zone has the capacity to store water but with little or no effects on the transmissivity. The transmissivity of the soil zone depends on multiple factors, such as the advancing speed of the mining face, surface water volume, and crack evolution state. The fractured zone generally plays the most important role in the water cycling system in overburden strata. The thickness of this zone differs considerably for different sites, and it is often expressed as a function of the mining height $h$ in Figure $5[24,25]$. The principle for the delimitation of the fractured water-inflow zone that is frequently used in Chinese coal mines is shown in Table 2 [25].

Table 2. Empirical expressions for the delimitation of the thickness of the fractured zone $(H)$ used in China [25].

\begin{tabular}{cc}
\hline Strength Rank of the Overlying Strata & Thickness of the Fractured Zone (m) \\
\hline Strong & $H=\frac{100 \Sigma h}{1.2 \sum h+2.0} \pm 8.9$ \\
Medium strong & $H=\frac{100 \Sigma h}{1.6 \sum h+3.6} \pm 5.6$ \\
Weak & $H=\frac{100 \Sigma h}{3.1 \sum h+5.0} \pm 4.0$ \\
Very weak & $H=\frac{100 \Sigma h}{5 \Sigma h+8.0} \pm 3.0$ \\
\hline
\end{tabular}

\subsection{Development Contradictions between Coal and Uranium}

Based on the aforementioned development of coal resources, a certain scope of strata above the coal seam is disturbed under the influence of coal mining face advancement. The disturbance can cause a water burst if an upper aquifer seam exists above the coal seam; a normal countermeasure to this problem is to artificially drain the water off in advance. This approach sounds technically reasonable, and a feasible solution works successfully in the majority of coal mines. However, this approach faces a bottleneck if there are mutualistic/accompanying resources existing around the coal seam. In this section, a representative field example from the Haggin Banner in the Ordos Basin is chosen as the research object; the resource distribution pattern is quite normal in most parts of the Ordos Basin.

The Tarangaole coal mine field is located in the Haggin Banner near the border of the Dalad Banner and serves as the first ten-million-ton annual coal production coal mine in the Shenhua Group. This field possesses an area of $230 \mathrm{~km}^{2}$, with the longest distance being $15.70 \mathrm{~km}$ from north to south and $25.50 \mathrm{~km}$ from east to west. The measured minable coal seams are 3-1, 4-1, 4-2, and 5-1, and the total coal reserves are 1.556 billion tons. The coal-bearing strata belong to the Middle/Lower 
Jurassic, and the geological structure is relatively simple. The main aquifers that may influence coal mining activity are the Cretaceous confined aquifer and Jurassic confined aquifer, and their average thicknesses are 188.42 and $174 \mathrm{~m}$, respectively.

At the eastern region of this coal field is the Nalinggou uranium mine, with an area of $32.86 \mathrm{~km}^{2}$. The occurrence horizon for uranium is Jurassic sandstone. The average burial depth is $410 \mathrm{~m}$, and the distances to the roof of coal seam 3-1, to the roof of the Jurassic confined aquifer, to the floor of the Jurassic confined aquifer, and to the floor of the Cretaceous confined aquifer are 90-150 m, 13-54 m, 80-147 m, and $210 \mathrm{~m}$, respectively.

In certain horizons under the coal seam, the occurrence horizons for oil and gas are verified at a burial depth of approximately $1500 \mathrm{~m}$. The co-existence situation between coal and uranium in the Tarangaole mine area is shown schematically in Figure 6.

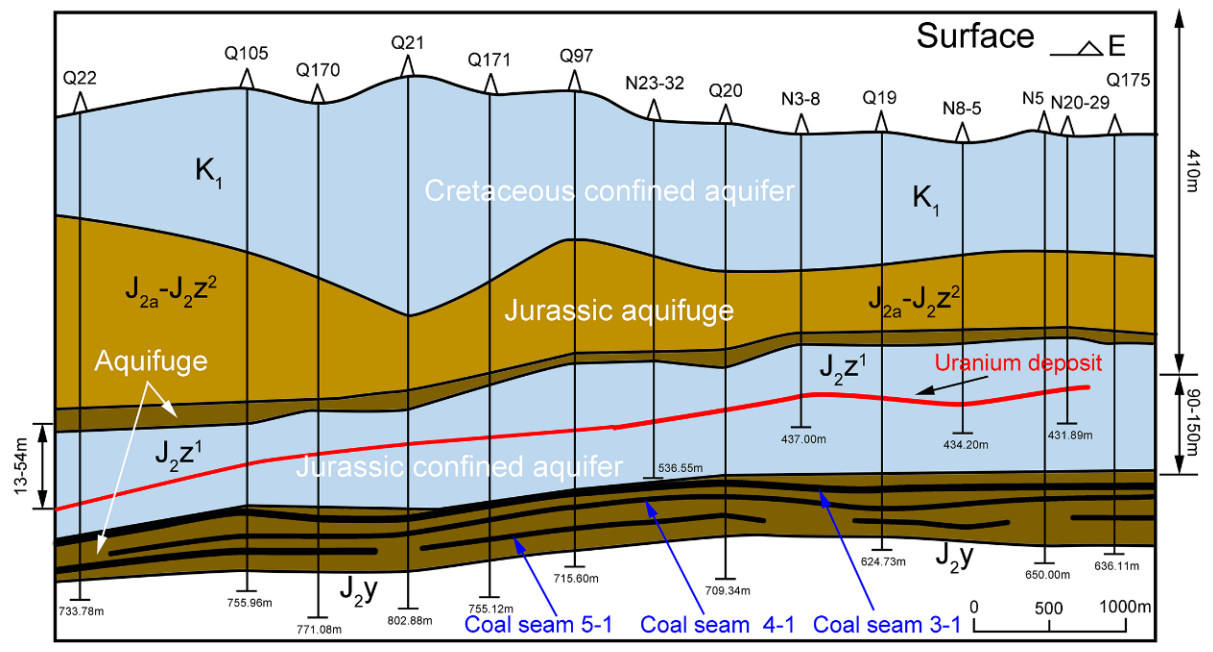

Figure 6. Schematic of the co-existence situation between coal and uranium in the Tarangaole mine area of the Haggin banner in the Ordos Basin.

Normal coal mining must first draw off the water, whereas uranium mining must first protect the water. Improper exploration of coal and uranium is likely to cause a major disaster to the local environment and ecosystem, especially for unscientific uranium mining. Uranium (U) is a nonessential and toxic heavy metal and radioactive element, and a possible leak of this element will certainly lead to the extinction of animals and plants [26,27]. Currently, to not import security and environment risks to local residents, it has been decided to abandon the original coal mining face under the uranium for the following main reasons: a) coal mining will induce a water downtrend phenomenon in the upper Jurassic confined aquifer, which is not allowed in the uranium mining horizon, and b) $\mathrm{U}^{4+}$ will be oxidized into $\mathrm{U}^{6+}$ under the strong oxidization environment of the leaching agent, dissociative uranium will migrate with the water flow, and it is possible for it to permeate into the lower coal mining face through the fractured cracks induced by strata caving, thus bringing radioactive contamination to the mine water and to the surface.

Because of the abandonment of the coal mining face in the eastern border of the coal field, the annual production of the coal resource has dropped from 10 to 6 million tons. Additionally, the originally equipped coal cleaning plant and railway are also left unused, which severely reduces the economic benefits of the Tarangaole coal mine.

\subsection{Exploitation Mode of Uranium}

The presented leaching solution is composed by $\mathrm{CO}_{2}, \mathrm{O}_{2}$, and water, which belongs to a neutral solution, whereas the traditional solutions show acidic/alkaline property. It hence decreases the contamination to groundwater system. From another perspective, if we take the same measure to 
uranium mining as what underground coal mining applied, then no more than one ton of uranium can be extracted if 1000 tons of ore is excavated underground because the average uranium-bearing ore grade of China is $0.1 \%$ or so. With the rest 999 tons of waste rock mass to process, it is for sure that large amount of surface area needs to be occupied. Furthermore, there also can produce 3000 tons of wastewater during the processing procedure, and the disturbance to the underground strata is also unrecoverable.

The exploitation method of uranium applied in this area is in situ leach technology $\left(\mathrm{CO}_{2}+\mathrm{O}_{2}\right)$, which includes the following five steps: pressing and injection of the leaching solution, measure/allocation and mixed injection of $\mathrm{CO}_{2}$, measure/allocation and mixed injection of $\mathrm{O}_{2}$, migration and extraction of the leaching solution in the ore-bearing strata, and surface transportation of the uranium-bearing leaching solution. A certain proportion of the leaching solution is injected into the uranium strata through a liquid-injection borehole from the ground surface, and then, the leaching solution will come into contact with the useful components in the ore to initiate a chemical reaction between bicarbonate ion and uranium. Finally, the valuable component uranium is dissolved and forms a uranium-bearing leaching solution. The solution is then extracted to the ground through a liquid-extraction borehole for further processes, such as ion exchange, elution, sediment, and filter pressing, to obtain final product. The overall technological process is shown in Figure 7.

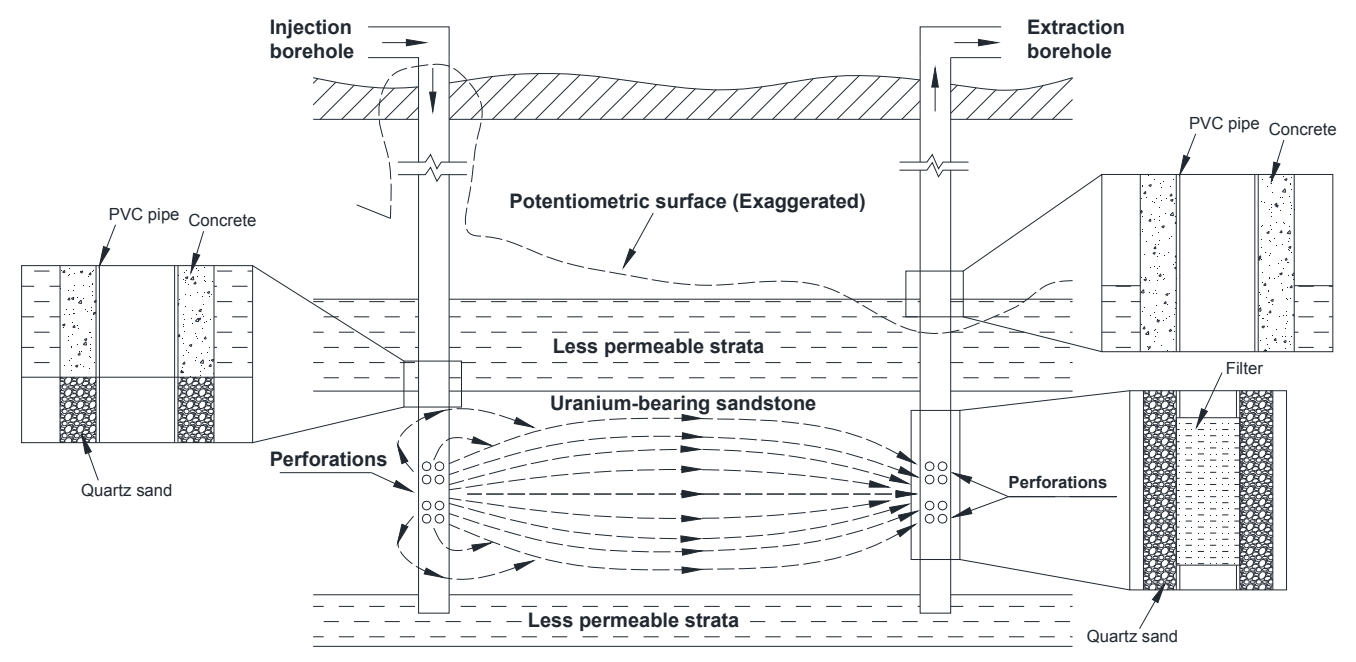

Figure 7. In situ leach technology for uranium exploitation and its influence on the groundwater level.

Based on this technology, the main emissions discharged into the environment include radioactive waste gas, radioactive wastewater, and radioactive solid waste. Radioactive waste gas is radon (Rn), which is generated by the decay of radium (Ra), which accompanies uranium. However, regardless of the exposure at the filter pressing section and wastewater evaporation section, the total leaching procedure is conducted in a closed circulation system, as indicated in Figure 7. In this manner, the release capacity of radon (Rn) can be dramatically reduced compared with other technologies.

The treatment on radioactive wastewater can be divided into two sections, the underground section and the surface section. In the underground section, the migration underground depends on the water pressure difference from a hydrogeological prospective. Hence, a certain influence radius exists around both the injection borehole and extraction borehole. The water level inside the radius varies, whereas the water level outside the radius remains constant. The water level peripheral in the injection borehole will increase, and the peripheral in the extraction borehole will decrease. The water level outside the radius will migrate downstream following a natural flow rate. To avoid the migration of radioactive elements in the underground water system and decrease the radius of influence, the measure of unbalanced injection and extraction is adopted, which means that the extraction volume is slightly larger than the injection volume. An appropriate potentiometric surface 
can then be formed, as shown in Figure 7, which guarantees the general flow trend of the leaching solution to the extraction borehole. By sustaining this flow direction, both the loss of uranium and the influence on the underground water system can be decreased. The extraction volume cannot be exaggerated compared with the injection volume for reducing the dilution of the peripheral water on the extraction solution and the wastewater treatment capacity of the surface sewage treatment plant. Generally, the injection/extraction ratio should be controlled at approximately $0.3 \%$. Though the potentiometric surface is an exaggerated existence, it does have several vital indexes that can evaluate the contamination based on the observation boreholes set up around the leaching field such as the indirect monitoring on radon and its daughters concentration in the air, natural $\mathrm{U}$ and ${ }^{226} \mathrm{Ra}$ in the resident water wells and in the upstream and downstream of the mining field, in addition to the ${ }^{238} \mathrm{U}$ and ${ }^{226} \mathrm{Ra}$ in surrounding soil and plants. The results did not show some obvious abnormal phenomena, which may indicate the appropriate existence of this potentiometric surface in groundwater system. Certainly, a lot of further work still needs to be conducted to precisely evaluate the influence to both the surface and underground around uranium mining field.

In addition, during the construction of the injection borehole and extraction borehole, it is strictly prohibited to let boreholes penetrate the lower less permeable strata, which can prevent the connectivity between uranium-bearing strata and its lower aquifer. In the segment where the borehole wall contacts the uranium-bearing strata, the annulus between injection/extraction pipe and borehole wall is filled by filter pipe and quartz sand filter; whereas in the segment where the borehole contacts the upper less permeable strata, this annulus is filled by PVC pipe and concrete specified by impermeable and anti-seismic properties. Hence, the uranium-bearing strata can be isolated from its neighboring upper less permeable strata and lower permeable strata to avoid contaminants moving in an underground aqueous system. The aforementioned explanation can be seen in Figure 7.

A sufficient number of observation boreholes are set up around the leaching field to monitor the diffusion of the leaching solution and uranium-bearing solution, including upstream/downstream/flanks of the ground water and the upper/lower aquifer strata. The redundant extraction liquid will be processed as useless wastewater by the sewage treatment plant. To eliminate the discharge of radioactive wastewater to the surface, certain evaporation ponds are constructed in view of the local natural evaporation capacity and wastewater output. The bottom of the pond is padded by clay that has considerable waterproofing capacity and a self-healing function. A high density polyethylene film is used to enhance the impermeability of the ponds. The monitoring procedure relying on observation boreholes started simultaneous with the construction of Nalingou uranium mine, even today, the observation still continues. Because we cannot guarantee a hundred-percent safe that the groundwater system is not contaminated, so we need to keep conducting environmental monitoring at regular time intervals.

Unlike in the coal mining procedure, complex roadways, shafts, and chambers should be constructed. Coal resources should be mined out to let roof caves so that a large amount of gangue is lifted to the surface to occupy farmland and damage the environment. Uranium mining does not produce solid waste because of the in situ leaching process. The solid waste includes instruments, equipment, and pipes, which are easily recycled.

In conclusion, in situ leaching technology has a series of advantages, such as (a) low production energy consumption and earlier investment; (b) low labor tension and good work conditions due to the lack of underground manual operation; (c) uranium resources are exploited at the maximum limit, and the production rate is greatly improved; and (d) minor contamination to the underground water circulation system and surface ecosystem.

\subsection{Development Contradictions between Coal and Natural Gas}

The natural occurrence horizon of oil and gas exceeds that of coal seams, and current exploitation and further exploration of oil and gas have significant impacts on the normal coal mining process because the drillings must pass through the coal seams for deeper resources. First, the oil and gas 
drillings are extremely intensive, with a general interval of $600 \mathrm{~m} \times 800 \mathrm{~m}$, and the dense oil/gas pipelines and drillings cause major disasters to coal mining. It is difficult to maintain a balance in their respective exploitation. The drillings are unobservable when the coal cutter is cutting the coal seam, and the drillings are easy to cut off by a coal cutter, triggering a pressing gas leakage. This leakage will trigger a coal mine gas explosion with high sensitivity, causing underground construction damage, personnel casualties, and economic losses. This situation determines the incompatible situations between coal mining and gas exploration/exploitation. Current coal mining-dominated exploitation wastes many opportunities to exploit deeper resources below coal seams. Second, the validity for gas/oil mining rights can be sustained for 40-70 years, and this duration can also be extended because of constant exploration. Such a long waiting time is clearly unrealistic for coal mining if only one resource can be mined during a specific period. However, the remaining drillings with residual gas/oil in it may still evolve as "landmines" for the next coal mining procedure.

\subsection{Experience Reference from Integrated Coal and Gas Production}

Integrated coal and gas production was first put forward to solve the problems in high-gas-content coal mines, where gas outbursts and gas explosions occurred frequently and caused major losses [28]. At present, this technology is mature and is successfully applied in many coal mines in China [29]. Unlike traditional thought regarding gas in coal seams as having no economic benefits, integrated coal and gas production combines coal mining and gas capture, preventing both gas-induced coal mine accidents and gas emissions. Coal seam gas is a strong contributor to the greenhouse effect and is approximately 25 times more potent than $\mathrm{CO}_{2}$ [30,31]; however, the gas can also be utilized to generate electricity. The three-dimensional diagram for integrated coal and gas production is shown in Figure 8.

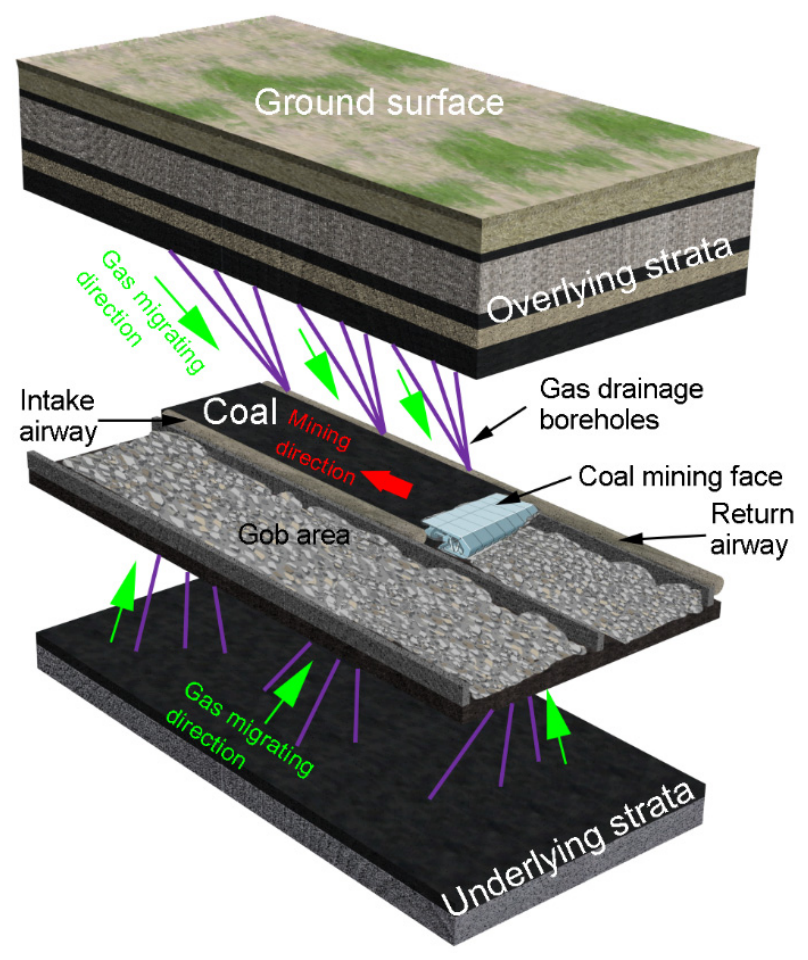

Figure 8. Three-dimensional diagram for integrated coal and gas production.

Integrated coal and gas production has a stringent requirement regarding the permeability of coal seams [32]. The high pressure in the coal seam should be relieved before drainage. Otherwise, the gas cannot be effectively drained because of its strong absorbability to coal body and the compactness of coal [33]. Under such circumstances, only the disturbance to the overlying strata and underlying strata 
can cause cracks and release the inner pressure, resulting in an increase in the volumetric dilation and the permeability of coal and allowing gas to drain freely [34,35].

Inspired by this technique, the gas/oil extraction above the coal seam can become reality in a particular situation, and it is also feasible for gas/oil extraction under the coal seam if the resources are sufficiently close. However, in the Ordos Basin, gas/oil typically occurs at a depth of $1000 \mathrm{~m}$ below the ground surface, which is too far away to the coal seam. Even a relatively high strength of coal mining cannot induce sufficient cracks extending to that type of depth. The lack of cracks will decrease the disturbance to the strata, which then causes many difficulties in draining gas/oil.

\section{Discussion and Future Outlook}

Under the surge of western development policy in China and the strategic western movement of national energy sources, Ordos has successfully grown from its original poverty to its current prosperity in recent years, with its gross regional production (59.2 billion in EUR) ranked 20th in all Chinese prefecture cities in 2014. However, because of the unfortunate energy exploitation situation in the Ordos Basin, abundant valuable resources have already been sabotaged or discarded, and environmental protection is lacking. To effectively solve this problem, a widely accepted consensus should first be reached among different mining rights of different energy resources and between mining corporations and governments.

Most people express concern regarding uranium mining from a psychological perspective, and local residents may be resistant to the exploitation of radioactive minerals. A scientific verdict on the possibility of co-mining uranium and coal must be reached, and in no circumstances should the leakage of radioactive elements be allowed. Currently, the coal mining procedure has already stopped leaving sufficient space and time for the normal mining procedure of uranium. After the termination of uranium, large-scale surface and underground radioactive elements monitoring must still be conducted to guarantee absolute safety. Coal mining can then continue at the original site, and a backfilling measure can be applied to protect the underground water system without a preliminary water drainage procedure in aquifer strata [4].

The development and design of gas/oil mining should leave space for the further development and design of coal mining. The coordination mechanism between gas/oil and coal mining should be initiated in response to the contradictions and conflicts during exploitation, and the space coordinates for oil/gas drillings and coal mining faces/roadways should be shared and compared to avoid interference between the exploration of the two resources.

In the near future, the synergy exploitation of coal and gas/oil will surely become a reality. Based on hydraulic fracturing technology [36,37], the injection of $\mathrm{CO}_{2}$ [38], and ultrasonic irradiation technology [39], the strata under the coal seam can be fully pressure relieved and can produce cracks to create abundant free channels [37]. Such efforts may enable the arrangement of pipelines through the strata to drain the gas/oil from the surface and coal mining galleries.

\section{Conclusions}

(1) The energy structure of China has long been dominated by its "rich coal, meager oil, and deficient gas". Hence, coal has contributed greatly to China's economy. However, coal production in the northeastern, eastern, and southern regions of China is now facing various types of problems, which forces coal production to transfer to the western and northern regions of China. There are multiple resources, such as uranium, natural gas, coal, and oil, in these regions, which induce exploitation contradictions among them.

(2) The Ordos Basin is the largest energy-based resources aggregation area in China, and many types of minerals were reserved in different evolution periods; mutualistic and accompanying occurrence patterns of different resources are common. The conflicts and contradictions among oil/gas, coal, and uranium are becoming increasingly prominent. 
(3) The coal mining procedure leaves numerous cracks in the strata above/below the gob area, which provide channels for water migration. Upper uranium mining can leave radioactive elements in water and will severely influence the workers' health and the natural water system. Hence, the coal mining procedure should leave sufficient space and time for the uranium mining procedure. During the exploitation of uranium, the measure of the unbalanced injection and extraction should be adopted to avoid the migration of radioactive elements in the underground water system.

(4) The extraction of oil/gas must be equipped with a sufficient number of pipelines and drillings, which bring some hidden dangers to the coal mining procedure. Additionally, the durations for mining rights of oil/gas and coal also conflict greatly with each other. Experience from integrated coal and gas production can be learned to coordinate the contradiction between coal and gas/oil exploitation, which is a foreseeable measure to be widely applied in the Ordos Basin.

(5) A widely accepted consensus should first be reached among the different mining rights of different energy resources and between mining corporations and governments. Each energy resource has its special role in industrial society. It is unwise to choose a fertile resource and abandon an infertile one or to choose one that is easy to exploit and ignore the remainder. A sustainable, environmentally friendly, and comprehensive resources utilization system must be established and popularized.

Acknowledgments: Financial support for this paper from the Fundamental Research Funds for the Central Universities (NO. 2014XT01), Program for Changjiang Scholars and Innovative Research Team in University (IRT_14R55), National Basic Research Program of China (2013CB227904), and Scientific Research Innovation Projects for College Graduate Students in Jiangsu Province (KYLX15_1400) is gratefully acknowledged.

Author Contributions: Xiaowei Feng proposed the idea. Nong Zhang, Xiaowei Feng and Chuangxin Lv conducted field research in the Nalinggou uranium mine and the Tanrangaole coal mine field in the Ordos Basin. Xiaoting Chen provided suggestions and assisted Xiaowei Feng in revising the manuscript. Xiaowei Feng wrote and revised the manuscript. Yu Guo created Figure 2. Nong Zhang supervised the project. All authors agree to be listed and approve the submitted and accepted versions of the publication.

Conflicts of Interest: The authors declare no conflict of interest.

\section{References}

1. Ministry of Land and Resources of the People's Republic of China. China Mineral Resources 2014; Geological Publishing House: Beijing, China, 2015.

2. U.S. Energy Information Administration, International Energy Data and Analysis. Available online: http:/ / www.eia.gov/beta/aeo/?src=-f2 (accessed on 13 November 2015).

3. Wang, L.; Watanabe, T.; Xu, Z. Monetization of external costs using life cycle analysis: A comparative case study of coal-fired and biomass Power Plants in Northeast China. Energies 2015, 8, 1440-1467. [CrossRef]

4. Feng, X.; Zhang, N.; Gong, L.; Xue, F.; Zheng, X. Application of a backfilling method in coal mining to realise an ecologically sensitive "Black gold" industry. Energies 2015, 8, 3628-3639. [CrossRef]

5. General Office of the State Council of the People's Republic of China, Energy Development Strategic Action Plan from 2014 to 2020. Available online: http://www.gov.cn/zhengce/content/2014-11/19/ content_9222.htm (accessed on 14 November 2015).

6. Yuan, L. Theory and practice of integrated coal production and gas extraction. Int. J. Coal Sci. Technol. 2015, 2, 3-11. [CrossRef]

7. Hu, G.; Xu, J.; Zhang, F.; Zhao, C.; Qin, W.; Zhu, Y. Coal and coalbed methane co-extraction technology based on the ground movement in the Yangquan Coalfield, China. Energies 2015, 8, 6881-6897. [CrossRef]

8. Cheng, Y.; Wang, L.; Liu, H.; Kong, S.; Yang, Q.; Zhu, J.; Tu, Q. Definition, theory, methods, and applications of the safe and efficient simultaneous extraction of coal and gas. Int. J. Coal Sci. Technol. 2015, 2, 52-65. [CrossRef]

9. $\mathrm{Xu}, \mathrm{Y}$. Using basalt geochemistry to constrain Mesozoic-Cenozoic evolution of the lithosphere beneath North China Craton. Earth Sci. Front. 2006, 13, 93-104. 
10. Bi, L.; He, H.; Wei, Z.; Feng, S. Fractal properties of landforms in the Ordos block and surrounding areas, China. Geomorphology 2012, 175-176, 151-162. [CrossRef]

11. Wang, C.; Sandvol, E.; Zhu, L.; Lou, H.; Yao, Z.; Luo, X. Lateral variation of crustal structure in the Ordos block and surrounding regions, North China, and its tectonic implications. Earth Planet. Sci. Lett. 2014, 387, 198-211. [CrossRef]

12. Ren, Z.; Zhang, S.; Gao, S.; Cui, J.; Xiao, Y.; Xiao, H. Tectonic thermal history and its significance on the formation of oil and gas accumulation and mineral deposit in Ordos Basin. Sci. China Ser. D Earth Sci. 2007, 50, 27-38. [CrossRef]

13. Li, R.; Li, Y. The geologic features of mineralization at the Dongsheng uranium deposit in the northern Ordos basin (Central China). Russ. Geol. Geophys. 2011, 52, 593-602.

14. Wang, M.; Luo, J.; Li, M.; Bai, X.; Cheng, C.; Yan, L. Provenance and tectonic setting of sandstone-type uranium deposit in Dongsheng area, Ordos basin: Evidence from U-Pb age and Hf isotopes of detrital zircons. Acta Petrol. Sin. 2013, 29, 2746-2758.

15. Gao, G.; Kang, G.; Li, G.; Bai, C. Crustal magnetic anomaly in the Ordos region and its tectonic implications. J. Asian Earth Sci. 2015, 109, 63-73. [CrossRef]

16. Booth, C.J. The effects of longwall coal mining on overlying aquifers. Geol. Soc. 2002, 198, 17-45. [CrossRef]

17. Peng, S.S. Coal Mine Ground Control, 3rd ed.; China University of Mining and Technology Press: Xuzhou, China, 2013.

18. Du, J.; Meng, X. Mining Science; China University of Mining and Technology Press: Xuzhou, China, 2009.

19. Singh, R.N.; Atkins, A.S. Design considerations for mine workings under accumulations of water. Int. J. Mine Water 1982, 1, 35-56. [CrossRef]

20. Kendorski, F.S. Effect of full-extraction underground mining on ground and surface waters: A 25-year retrospective. In Proceedings of the 25th International Conference on Ground Control in Mining, Morgantown, WV, USA, 1-3 August 2006; pp. 425-430.

21. Fan, G.; Zhang, D. Mechanisms of aquifer protection in underground coal mining. Mine Water Environ. 2015, 34, 95-104. [CrossRef]

22. Singh, R.; Mandal, P.K.; Singh, A.K.; Kumar, R.; Maiti, J.; Ghosh, A.K. Upshot of strata movement during underground mining of a thick coal seam below hilly terrain. Int. J. Rock Mech. Min. 2008, 45, $29-46$. [CrossRef]

23. Singh, M.M.; Kendorski, F.S. Strata disturbance prediction for mining beneath surface water and waste impoundments. In Proceedings of the 1st Conference on Ground Control in Mining, Morgantown, WV, USA, 27-29 July 1981; pp. 76-89.

24. Yavuz, H. An estimation method for cover pressure re-establishment distance and pressure distribution in the goaf of longwall coal mines. Int. J. Rock Mech. Min. 2004, 41, 193-205. [CrossRef]

25. Du, J.; Wang, L. Special Coal Mining Method; China University of Mining and Technology Press: Xuzhou, China, 2003.

26. Tewari, R.; Horemans, N.; Nauts, R.; Wannijn, J.; Van Hees, M.; Vandenhove, H. Uranium exposure induces nitric oxide and hydrogen peroxide generation in Arabidopsis thaliana. Environ. Exp. Bot. 2015, 120, 55-64. [CrossRef]

27. Joksic, A.S.; Katz, S.A. Chelation therapy for treatment of systemic intoxication with uranium: A review. J. Environ. Sci. Health Part A Toxic Hazard. Subst. Environ. Eng. 2015, 50, 1479-1488. [CrossRef] [PubMed]

28. Wang, L.; Cheng, Y.; Liu, H. An analysis of fatal gas accidents in Chinese coal mines. Saf. Sci. 2014, 62, 107-113. [CrossRef]

29. Xue, F.; Zhang, N.; Feng, X.; Zheng, X.; Kan, J. Strengthening borehole configuration from the retaining roadway for greenhouse gas reduction: A Case Study. PLoS ONE 2015, 10, e115874. [CrossRef] [PubMed]

30. IPCC, 2007: Climate Change 2007: Synthesis Report. Contribution of Working Groups I, II and III to the Fourth Assessment Report of the Intergovernmental Panel on Climate Change; Pachauri, R.K., Reisinger, A., Eds.; IPCC: Geneva, Switzerland, 2007; p. 104.

31. Wang, L.; Cheng, Y.; An, F.; Zhou, H.; Kong, S.; Wang, W. Characteristics of gas disaster in the Huaibei coalfield and its control and development technologies. Nat. Hazards 2014, 71, 85-107. [CrossRef]

32. Lu, S.; Cheng, Y.; Qin, L.; Li, W.; Zhou, H.; Guo, H. Gas desorption characteristics of the high-rank intact coal and fractured coal. Int. J. Min. Sci. Technol. 2015, 25, 819-825. [CrossRef] 
33. Tao, S.; Tang, D.; Xu, H.; Gao, L.; Fang, Y. Factors controlling high-yield coalbed methane vertical wells in the Fanzhuang block, Southern Qinshui Basin. Int. J. Coal Geol. 2014, 134-135, 38-45. [CrossRef]

34. Bustin, R.M.; Cui, X.; Chikatamarla, L. Impacts of volumetric strain on $\mathrm{CO}_{2}$ sequestration in coals and enhanced $\mathrm{CH}_{4}$ recovery. AAPG Bull. 2008, 92, 15-29. [CrossRef]

35. Pan, Z.; Connell, L.D. Modelling permeability for coal reservoirs: A review of analytical models and testing data. Int. J. Coal Geol. 2012, 92, 1-44. [CrossRef]

36. Wang, W.; Li, X.; Lin, B.; Zhai, C. Pulsating hydraulic fracturing technology in low permeability coal seams. Int. J. Min. Sci. Technol. 2015, 25, 681-685. [CrossRef]

37. Shen, C.; Lin, B.; Sun, C.; Zhang, Q.; Li, Q. Analysis of the stress-permeability coupling property in water jet slotting coal and its impact on methane drainage. J. Petrol. Sci. Eng. 2015, 126, 231-241. [CrossRef]

38. Yu, H.; Jing, R.; Wang, P.; Chen, L.; Yang, Y. Preferential adsorption behaviour of $\mathrm{CH}_{4}$ and $\mathrm{CO}_{2}$ on high-rank coal from Qinshui Basin, China. Int. J. Min. Sci. Technol. 2014, 24, 491-497. [CrossRef]

39. Xiao, X.; Pan, Y.; Lu, X.; Yang, X. Mechanism of methane permeability enhance through ultrasonic irradiating on low permeable coal seam. Chin. J. Geophys. 2013, 56, 1726-1733. (In Chinese)

(C) 2016 by the authors; licensee MDPI, Basel, Switzerland. This article is an open access article distributed under the terms and conditions of the Creative Commons by Attribution (CC-BY) license (http:/ / creativecommons.org/licenses/by/4.0/). 